\title{
Development planning ranch area based on the potential of feeding ruminants in Aceh, Indonesia
}

\author{
Firda Farida Rahmah*, Fawwa Rahly, and Yenni Yusriani \\ Aceh Assessment Institute for Agricultural Technology, Jalan Pang. Nyak Makam No. 27, Banda \\ Aceh, Aceh, Indonesia,
}

\begin{abstract}
The research objectives were: (1) to determine which ruminants could be developed based on regional resource support; and (2) to identify the potential of agricultural waste to support livestock development in Pidie Regency, Aceh. This research used descriptive and exploratory methods. The descriptive method described the condition of development of potential forage areas in the Pidie district. The population data for large ruminants was calculated based on the population structure of production (weaning, young, adult, and imported cattle). Furthermore, the population based on age was converted into Animal Unit (AU). The results found that the Pidie regency had the potential for livestock development. The sub-districts of Padang Tiji had an ample opportunity as producer of rice farming waste with a total of 4,734.80 tonnes/year, maize 81.3; cassava 12.5; soybean 4.95; green beans 1.37 and peanuts $0.822 \mathrm{DDM}$ tonnes/year. The potential that had not been utilized was 4,241.57 tonnes/year and has a capacity of 3,720.68 (ST/year), followed by Sakti district and Mutiara Timur districts. The conclusion showed Pidie Regency can increase the population of ruminants by increasing the benefits of feed from agricultural waste.
\end{abstract}

\section{Introduction}

The paradigm of livestock development is how to achivehe of a healthy, productive and creative of the community through resilient livestock based on local resources. There are several visions that must be achieved including: (a) providing food from livestock, (b) empowering livestock human resources, (c) increasing livestock income, (d) creating livestock jobs, and (e) conserving and utilizing natural resources, which as a whole it is in line with the agricultural development program, namely building food security and developing the agricultural agribusiness sector [1]. According to [2], the main challenge in developing livestock business in one region is the existence of a livestock business area development program that will increase livestock productivity through optimization of local resources and local wisdom. Indonesia is an agricultural country with abundant natural resources. Focusing on developing the agricultural sector, it will have the opportunity to become a developed country that always gets top priority in every national leadership [3].

One of the failures in develops the livestock population in an area is basically not concern into measurement of the carrying capacity of the available feed, obviously the feed is the

* Corresponding author: ff.firdafarid@gmail.com 
largest input to the livestock system [4]. Livestock developmnet is closely related to the development of an area. On the other hand, there has been a change in the function of land which previously provided a source of feed to become wetland / agriculture to meet the demands of food supply due to the increasing population. In addition, the provision of feed also has limitations due to the competing needs for food supply for human consumption.

The natural resources remain the main basis for running livestock business activities, especially ruminants. As a provider of feed, the linkage between food crop production areas and livestock production becomes an essence in the livestock development process [5]. Furthermore, [6] states that agricultural waste is feed sourced from food crop waste and its production is highly dependent on the type and number of planted areas of food crops in an area. Agricultural waste is categorized as feed with high fiber and low protein, such as: corn straw, rice straw, peanut straw and others; and also feed with high crude fiber and high protein in the form of agricultural industrial waste such as rice bran and corn bran, and others.

Pidie District as one of the districts in Aceh Province has the potential for livestock development both in the agro-climate aspect and the socio-economic community performance. One of the efforts that can be made to facilitate the development of sustainable livestock development is by identifying the potential areas based on the measurements of resources used by the livestock sector. Therefore, the objectives of this paper are (1) to determine which ruminant livestock commodities can be seeded based on regional resource support; (2) identify the potential for agricultural waste to be used as a basis for livestock development in Pidie Regency.

\section{Methodology}

\subsection{Theory and methods}

This research uses descriptive and exploratory methods. The descriptive method aims to describe the development conditions of the potential forage area in the Pidie Regency. The secondary research data were obtained from the Central Statistics Agency for Pidie Regency in 2017 and 2018. The data collected were from livestock population data and food crop harvest data in Pidie Regency. The carrying capacity of agricultural waste for animal feed is calculated based on the number of livestock units in the Pidie district.

\subsection{Observed variables}

The population data for large ruminants are calculated based on the population structure of production (weaning, off weaning, young, adult and imported cattle) and buffalo (off weaning, young, adult). a) Wean with age $<1$ year has a composition of $19.30 \%$ of the population; (b) Off weaning $>1$ year old has a composition of $25.85 \%$ of the population; (c) Young people aged 2-4 years have a composition of $18.15 \%$; (d) Adults $>4$ years old have a composition of $26.89 \%$; and (5) Imported cattle have a composition of $9.81 \%$. For buffalo livestock with a buffalo population structure based on age are (a) Wean off as a composition of $16.32 \%$ of the population; (b) Young has a composition of $20.67 \%$ of the population; (c) Adults (2-4 years) have a composition of $20.74 \%$; (d) Adults ( $>4$ years) have a composition of $42.27 \%$; Furthermore, population based on age is converted into Livestock Unit (ST), which is a unit to equalize one adult ruminant livestock. The unit value of beef cattle according to [9] is $0.25 \mathrm{ST}$ for children (weaning and weaning), 0.6 ST (young) and 1.00 (adults and imports). The unit value of buffalo is calculated according to [10], namely 0.8 ST. 
The minimum requirement for large ruminant animal feed using the calculation [11], is 1.14 tonnes DDM / year. Estimated production of food crop waste per hectare per year which is calculated based on estimates of food crop production with data sources from the Food Crops and Horticulture Office of Pidie Regency with calculations according to [11].

\section{Results and discussion}

\subsection{Geographical condition of Pidie Regency}

Astronomically, Pidie Regency is located between $04,30^{\circ}-04,60^{\circ}$ North latitude, and between $95,75^{\circ}-96,20^{\circ}$ East. Pidie Regency is consist of lowland and upland areas, it is located between $04,30^{\circ}-04,60^{\circ}$ north latitude, $95,75^{\circ}$ and $96,20^{\circ}$ east longitude. Pidie Regency area is shaped in landby $3.562,14 \mathrm{~km}^{2}$. In 2018 , Pidie Regency is divided into twenty three subdistricts (Table 1). Territorial Boundaries of Pidie Regency in northern area bordered by Malaca, eastern area border on Pidie Jaya Regency, southern area border on Aceh Barat Regency and Aceh Jaya Regency, and western area bordered by Aceh Besar Regency.

Table 1. The area of the sub-district in Pidie district

\begin{tabular}{|c|l|c|}
\hline No & \multicolumn{1}{|c|}{ Subdistricts } & Area $\mathbf{( k m}^{2} \mathbf{~}$ \\
\hline 1. & Geumpang & 594,64 \\
\hline 2. & Mane & 817,50 \\
\hline 3. & Glumpang Tiga & 59,70 \\
\hline 4. & Glumpang Baro & 45,30 \\
\hline 5. & Mutiara & 35,05 \\
\hline 6. & Mutiara Timur & 63,55 \\
\hline 7. & Tiro/Truseb & 255,00 \\
\hline 8. & Tangse & 755.00 \\
\hline 9. & Keumala & 27,57 \\
\hline 10. & Titeue & 20,11 \\
\hline 11. & Sakti & 70,03 \\
\hline 12. & Mila & 21,32 \\
\hline 13. & Padang Tiji & 258,71 \\
\hline 14. & Delima & 43,89 \\
\hline 15. & Grong-grong & 19,41 \\
\hline 16. & Indrajaya & 34,02 \\
\hline 17. & Peukan Baro & 30,00 \\
\hline 18. & Kembang Tanjong & 46,50 \\
\hline 19. & Simpang Tiga & 55,36 \\
\hline 20. & Kota Sigli & 9,75 \\
\hline 21. & Pidie & 38,00 \\
\hline 22. & Batee & 104,74 \\
\hline 23. & Muara Tiga & 162,00 \\
\hline & &
\end{tabular}

The Large Ruminant livestock (cattle and buffalo) are important for the sustainable life of the people in Pidie Regency. In general, beef cattle and buffalo are scattered in all districts. The largest population of large ruminants is beef cattle, followed by buffalo. Large ruminant populations are presented in Tables Attachment 2 and 3.

Based on Table Attachment 2, the area with the highest population of beef cattle is Padang Tiji sub-district with a total of 7,022 heads $(4,134 \mathrm{ST})$ with a percentage of 10.69 followed by Mutiara Timur district with a number of 5,156 heads $(3,036 \mathrm{ST})$ with a percentage of 7.85 and Pidie sub-district with a percentage of 5.016 heads ( 2.953 ST) with a percentage of 7.63 
and the lowest sub-district is Mane with a total of 72 heads (42 ST) with a percentage of 0.11 . The region with the highest population of buffalo, namely Tangse sub-district with a total of 1,348 heads $(2,747$ ST) with a percentage of 24.90 followed by Padang Tiji sub-district with a total of 1,381 heads (678 ST) with a percentage of 12.52 and Geumpang sub-district with a total of 1,121 heads (550 ST). ) with a percentage of 10.16 and the lowest sub-district is Sigli City with a total of 14 heads (7 ST) with a percentage of 0.13 .

The leading ruminant commodities are determined based on the population development in Pidie Regency. Even though there are quite a number of criteria in determining which livestock have the potential to be superior in an area, population performance is believed to be the main indicator that can provide a principal picture of the comparative advantage of an area in maintaining the level of the livestock population concerned. Ruminant maintenance systems in the Pidie district range from extensive to intensive. Intensive maintenance (feedlots) are undertaken by advanced breeders and entrepreneurs. Meanwhile, those that are raised at the level of smallholder breeders are very diverse, ranging from how they are grazed in upland areas to semi-intensive maintenance systems.

Buffalo livestock is a genetic resource for local livestock whose contribution to the meat self-sufficiency program was recognized in 2010 [12] and for the maintenance in Pidie District, buffalo are scattered in all districts. Based on the place of life, buffalo are divided into two, namely the swamp buffalo (swamp buffalo) which is known as the slaughter type buffalo and the riverine buffalo (riverine buffalo) as the dairy buffalo. The population of river buffalo or dairy buffalo is only found in North Sumatra, while swamp / mud buffalo are scattered throughout Indonesia with populations, especially in East Nusa Tenggara, West Nusa Tenggara, Aceh, North Sumatra, West Sumatra, West Java, Banten, Central Java, and South Sulawesi [8].

\subsection{The Potential of feed}

Livestock population growth in an area is strongly supported by the availability of available feed production from one of the agricultural waste. Dry matter production is the amount of feed production from agricultural waste and feed production from natural forages. The potential amount of waste from each food crop is the current potential for potential feed availability. Potential waste is calculated from the residual production of food crops such as lowland rice straw, corn, soybeans, green beans, peanuts and cassava [13]. Thus the mixture of rice straw, corn straw, waste beans, cassava leaves and cassava is sufficient to support the basic needs of life and the growth of cattle and buffalo. Currently breeders have added concentrate to compensate for the lack of nutrients from agricultural waste. The use of waste as feed is generally carried out by farmers who own land and cultivate (plant) agricultural commodities [14].

Rice straw and corn straw can be used as a source of fiber and often processed in the form of preservation in the form of silage or hay to be used in the dry season. Other agricultural crop wastes such as beans, cassava leaves and wood are used as a source of protein feed, to complement the lack of protein from straw or corn straw. Potential feed and total agricultural waste can be seen in Table Attachment 4.

The high total production of agricultural waste is in the Padang Tiji sub-district of 4,835.79 tonnes / year, followed by the Sakti sub-district of 4,171.14 tonnes / year and 3,132.93 DDM tonnes / year of Mutiara Timur and a low sub-district, namely Sigli City because this sub-district is the capital of Pidie Regency. The agricultural commodities that produced the most agricultural waste came from rice, with 41,509.73 tonnes / year, followed by cassava 461.7 , peanuts 390.45 ; corn 325.8 ; soybean 249.48 and the last green bean 172.89 tonnes / year DDM. In terms of nutrition, the provision of agricultural agriculture does not meet the requirements to meet nutritional intake for livestock. The results of research from 
several experts for the management of feeding on ruminants are highly recommended with the addition of other feeds such as forage, silage, and concentrates.

Buffaloes get feed when grazing in the field, rice fields, and roadside. Buffalo has its own features compared to cows. Buffalo are able to live in areas with low quality available feed. Under these conditions, if buffaloes and cows are raised together, the growth and reproductive performance of buffalo will be better than cows [15]. Furthermore, [16] stated that the reproductive process of buffalo is very slow, characterized by slow puberty and long distance to give birth as well as cases of calm heat. All of them are influenced by nutrition, environment, and management [17]. The results of a study $43 \backslash[18]$ reported that adequate feeding during the growth period can accelerate puberty and childbirth. Buffalo milk is richer in important mineral content, namely $92 \% \mathrm{Ca}, 38 \% \mathrm{Fe}$, and $118 \% \mathrm{P}$, lower cholesterol content $(0.65 \mathrm{mg} / \mathrm{g})$ than cow milk $(3.14 \mathrm{mg} / \mathrm{g})$ and vitamin A content higher [19]. If it is seen in Table Attachment 5 that the potential for waste originating from agriculture is all available in the districts, except for the city of Sigli and a shortage of feed can be anticipated from other wastes such as plantations and concentrates as additional feed for ruminants.

\subsection{Regional supporting capacity based on the potential feed}

In general, the sub-districts in Pidie district have the potential for livestock development. Based on Table Attachment 5. Sub-districts that have a great opportunity are Padang Tiji subdistrict by producing waste from rice farming totaling 4,734.80 tonnes/ year, corn 81.3; cassava 12.5; soybean 4.95; green beans 1.37 and finally peanuts $0.822 \mathrm{DDM}$ tonnes/ year, the potential that has not been utilized is $4,241.57$ tonnes / year and has a capacity capacity of 3,720.68 (st/ year) followed by the potential untapped Sakti district 3,658.90 tons / year and has a capacity of 3,209.56 (st/year) and Mutiara Timur sub-district, the potential that has not been utilized is 2,748.18 tons / year and has a capacity of 2,410.69 (st/year). The Glumpang Tiga subdistrict and Sigli City in Pidie regency are sub-districts that do not have the potential for livestock development, which is for Sigli City is an urban area.

The livestock development is a very important part of national development as an effort to achieve food sovereignty, agribusiness development and increase the welfare of breeders in one area [20]. In connection with the provision of feed, the digestive physiological ability of buffalo is a little special because it is able to utilize feed with poor quality (roughage). However, the orientation of buffalo rearing is still related to carbau cultivation. In small rice fields with heavy contours, buffalo are still more practically utilized as a supporting factor in a more progressive cultivation of buffalo, as a meat producer as well as a source of labor. Buffalo has the ability to live in relatively difficult areas with low quality feed [21].

The Identification of the zoning of ruminants related to feed should also be linked to the livestock business patterns carried out by the community. The pattern of maintenance carried out of course has consequences for the provision of feed which is further influenced by the characteristics of the area where maintenance is carried out. Utilization of agricultural waste is one solution to meet the forage needs of ruminants [22]. The farmers defeat the problem of feed availability by utilizing agricultural waste in the form of rice straw, corn straw and legume waste in the livestock crop integration system in Aceh province [23]. With the integrated system can reduce production costs, efficient use of resources, increase production and farmers' income $[24 ; 25]$. They conducting the maximum using of agricultural crop waste feed available in pidie district, the types of livestock developed in each region must be adapted to the local socioculture, climate, topography, agro-ecosystem and supporting infrastructure.

The spread and development of livestock in one area aims to establishing livestock areas, developing inter-regional balance, optimizing resources to increase livestock income, population and production in the context of community empowerment [26]. Constraints for 
livestock producers are fluctuating feed availability resulting in lack of forage supply, communal land tenure, access to land resources, limited water, weak institutions, and lack of infrastructure. This can be overcome by improving the feed base, namely increasing the availability of feed, but this effort requires knowledge, understanding of the behavior of local farmers, and the ability to communicate [27].

The development of an integrated livestock business is a pillar of socio-economic development; success is determined by strategic policy support that includes three main dimensions of agribusiness, which include input market policies, cultivation, and marketing by involving the government, the private sector, and the farming community [28]. Livestock development is not only focused on efforts to encourage animal protein consumption, increase productivity, and realize self-sufficiency, but livestock revitalization should be more emphasized on efforts to achieve self-reliance, animal food security, farmer welfare, and business sustainability [29]. [30] states that planning in livestock-based regional development must integrate the advantages of commodities, ecological/land suitability, and socioeconomic characteristics as well as support for feed availability based on the carrying capacity of the area itself. Furthermore, [31] added that the placement of livestock in an area must consider land suitability, availability of forage, waste from agricultural/plantation products, and skilled human resources as a strategic step in optimally utilizing resources and considering sustainability based on a basic understanding of nature, natural characteristics of the land and livestock behavior. Livestock business in the future can be developed through an area-based model adapted to the region's capabilities, one of which is carrying capacity. The need for feed can be met by integrating animal husbandry with food crops, plantations, and forestry so that the activity becomes a profitable business. The development of the ruminant feed industry based on local raw materials can trigger the growth of domestic meat production and increase farmers' income [32].

\section{Conclusion}

Based on ruminant livestock commodities and agricultural waste potential, Padang Tiji subdistrict has a great opportunity as a rice agricultural waste-producing area with 4,734.80 tons/year, 81.3 corn; cassava 12.5; soybeans 4.95; green beans 1.37 and peanuts 0.822 DDM tons/year. The untapped potential is $4,241.57$ tons/year, and the capacity is $3,720.68$ (ST/year) in Pidie Regency. The livestock development policy can be implemented by determining the development area based on regional potential, increasing the role of institutions, and monitoring and evaluating periodically from the central and regional governments.

\section{References}

1. J.A. Syamsu, A. Abdullah. Jurnal Ekonomi Pembangunan. 10, 2: 199 (2014)

2. F. Fathurohman Analisis Pengembangan Wilayah Peternakan Sapi Potong di Kabupaten Subang. Jurnal Ilmiah Ilmu Dan Teknologi Rekayasa, 1 (2) :118-123

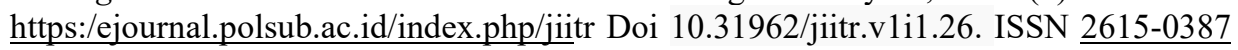
(online) (2018).

3. Y. Yusriani. Pemanfaatan Sumber Daya Lokal dan Kebijakan Pertanian Bioindustri. Model Pertanian Bioindustri: Perspektif Kebijakan, Teoritis dan Praksis. ISBN: 978623-93937-8-6. Bunga Rampai. Diterbitkan pertama kali oleh Penerbit Agro Indo Mandiri. Anggota IKAPI, No. 323/JBA/2018. Pp 19-34 (2020)

4. U.A. Tanuwiria, A. Budiman, B. Ayuningsih JIT, 15, 1: 56-69 (2015)

5. A.R. Daud. Sosiohumaniora, 11, 2:126-139 (2009) 
6. P.R. Matitaputty, B. Kuntoro. J. P. ISSN 1829 - 8729.7 (2) :70-81. (2010)

7. Pidie Central Statistics Agency. Pidie District in Figures. ISSN 2355-4896. Publisher BPS Pidie Regency (2019)

8. Directorate General of Animal Husbandry RI. General Guidelines for the Development of Cattle Integration in 2012.

9. A.J. Nell, D.H.L. Rollington. The Requirement and Availability of Livestock Feed in Indonesia. Jakarta, Indonesia: Working Paper. (1974)

10. Ashari, F., E. Juarini, Sumanto, B. Wibowo dan Suratman. Guidelines for analysis of potential areas for distribution and development of livestock. Center for Animal Research and Directorate of Livestock Spread and Development Development, Jakarta (1995)

11. Sumanto, E. Juarini.. Pedoman Identifikasi Potensi Wilayah. Balai Penelitian Ternak Ciawi-Bogor, Bogor 2006

12. L.S. Utami, S. Baba, S.N. Sirajuddin. JITP,4(3): 146-150 (2016)

13. E. Suhaema, Widiatmaka, B. Tjahjono.. J. Tanah Lingk. ISSN 1410-7333. 16, 2 : 53-60 (2014).

14. Y. Yusriani. Potensi Pakan Asal Limbah Pertanian Di Kabupaten Gayo Lues. JA, 4, 2 : 105-113. Available online at www.jurnal.abulyatama.ac.id/agriflora ISSN 2549-757X (Online) (2020).

15. K. Diwyanto, E. Handiwirawan. Strategi Pengembangan Ternak Kerbau: Aspek Penyaringan dan Distribusi. Prosiding Lokakarya Nasional Usaha Ternak Kerbau Mendukung Program Kecukupan Daging Sapi, Sumbawa, 4-5 Agustus 2006. Puslitbang Peternakan bekerja sama dengan Direktorat Perbibitan Ditjen Peternakan, Dinas Peternakan Provinsi NTB dan Pemda Kabupaten Sumbawa. Pp 3-12. (2006).

16. V. Paul, B.S. Prakash. Efficacy of the Ovsynch Protocol. For Synchronization of Ovulation and Fixed Time Artificial Insemination in Murrah Buffaloes (Bubalus Bubalis). Theriogenology 64: 1049-1060 (2005).

17. A.S. Nanda, P.S. Brar, S. Prabhakar. Enhancing Reproductive Performance in Dairy Buffalo; Major Constraint and Achievement. Proc. The Sixth International Symposium on Reproduction in Domestic Ruminants Vol. 61, Crieff. Scotland Uk. Pp. 27-36. (2003).

18. T.N. Pasha. Buffalo Bull. 32 (Special Issue 1): 91-110. (2013).

19. L. Febrina. Analisis Usaha Ternak Kerbau pada Ketinggian Tempat Yang Berbeda di Provinsi Sumatera Barat. Tesis Program Pascasarjana Universitas Andalas, Padang. (2010).

20. Y. Yusriani. Kinerja Reproduksi Sapi Potong Melalui Inovasi dan Teknologi Mineral Blok dan Indigofera di Kabupaten Bener Meriah dan Aceh Tengah. Akselerasi Peningkatan Produktivitas Sapi Potong dan Kerbau Melalui Teknologi Inovatif Mendukung Upsus SIWAB. (C2020 IAARD PRESS. Anggota IKAPI NO: 445/DKI/2018. ISBN 978-602-344-298-0. Pp 377-402 (2020).

21. C.H. Maureen, E. Kardiyanto. Potency of Developing. Buffalo In Banten Province for Supporting Beef Self Sufficiency. Prosiding Seminar dan Lokakarya Nasional Usaha Ternak Kerbau. Lebak Banten (ID):121-126. (2011).

22. D.N. Edi. Jurnal Sain Peternakan Indonesia. P-ISSN 1978-3000. E-ISSN 2528-7109. 15, 3: 251-258. Available at https://ejournal.unib.ac.id/index.php/jspi/index DOI: https://doi.org/10.31186/jspi.id.15.3.251-258 (2020).

23. Y. Yusriani, Elviwirda, M. Sabri. Jurnal Peternakan Indonesia 17, 2: 163-169 (2015).

24. Gunawan, A. Sulastiyah. J.Ilmu-Ilmu Pertanian. 6, 2: 157-168. (2010).

25. S. Soeharsono. K, Rustijarno, Triwidyastuti. Sains Peternakan. 6, 1: 49-55. (2017).

26. T. Rahman. JIR. 11, 1:60-73 (2018). 
27. H. Mayulu and T. P. Daru. Region Based of Animal Husbandry Development Policy: A Case Study in East Kalimantan. Review. Journal of Tropical AgriFood 1(2): 49-60 pISSN 2685-3590. e-ISSN 2685-3604 (2019).

28. H. Mayulu, Sunarso, Sutrisno, C.I., Sumarsono. JLP, 29, 1: 34-41 (2010)

29. K. Diwyanto, Priyanti, A. Pengembangan Inovasi Pertanian, 2, 3, 208-228 (2009)

30. W.Darsono, Putri E.I.K., and Nahrowi. JIPTHP, 04, 3: 356-363 (2016)

31. E. Suhaema, Widiatmaka, and Tjahyono, B. Journal. Tanah Lingk., 16, 2: 53-60 (2014)

32. N. Ilham. Alternatif Kebijakan Peningkatan Pertumbuhan PDB Subsektor Peternakan Di Indonesia. Analisis Kebijakan Pertanian, 5, 4: 335-357. (2007) 


\begin{tabular}{|c|c|c|c|c|c|c|c|c|}
\hline Sub-District & $\begin{array}{c}\text { Cow } \\
\text { Population } \\
\text { (unit) }{ }^{1}\end{array}$ & $\begin{array}{c}\text { Cow } \\
\text { Weaning } \\
\text { Population } \\
\text { (unit) }^{2}\end{array}$ & $\begin{array}{c}\text { cow after } \\
\text { Weaning } \\
\text { Population } \\
\text { (unit) }^{2}\end{array}$ & $\begin{array}{l}\text { Veal Cow } \\
\text { Population } \\
\text { (unit) }^{2}\end{array}$ & $\begin{array}{l}\text { Adult Cow } \\
\text { Population } \\
\text { (unit) }^{2}\end{array}$ & $\begin{array}{l}\text { Cow import } \\
\text { Population } \\
\text { (unit) }^{2}\end{array}$ & $\begin{array}{c}\text { Beef cattle } \\
\text { population } \\
(\mathrm{ST})^{3}\end{array}$ & $\begin{array}{c}\text { Percentage } \\
(\%)\end{array}$ \\
\hline Geumpang & 85 & 16.41 & 21.97 & 15.43 & 22.86 & 8.34 & 50 & 0.13 \\
\hline Mane & 72 & 13.90 & 18.61 & 13.07 & 19.36 & 7.06 & 42 & 0.11 \\
\hline Glumpang Tiga & 3.357 & 647.90 & 867.78 & 609.30 & 902.70 & 329.32 & 1.977 & 5.11 \\
\hline Glumpang Baro & 3.915 & 755.60 & 1.012 .03 & 710.57 & 1.052 .74 & 384.06 & 2.305 & 5.96 \\
\hline Mutiara & 3.156 & 609.11 & 815.83 & 572.81 & 848.65 & 309.60 & 1.858 & 4.80 \\
\hline Mutiara Timur & 5.156 & 995.11 & 1.332 .83 & 935.81 & 1.386 .45 & 505.80 & 3.036 & 7.85 \\
\hline Tiro/Truseb & 1.491 & 287.76 & 385.42 & 270.62 & 400.93 & 146.27 & 878 & 2.27 \\
\hline Tangse & 1.183 & 228.32 & 305.81 & 214.71 & 318.11 & 116.05 & 697 & 1.80 \\
\hline Keumala & 1.183 & 220.60 & 295.47 & 207.45 & 307.35 & 112.13 & 673 & 1.74 \\
\hline Titeue & 716 & 138.19 & 185.09 & 129.95 & 192.53 & 70.24 & 422 & 1.09 \\
\hline Sakti & 3.218 & 621.07 & 831.85 & 584.07 & 865.32 & 315.69 & 1.895 & 4.90 \\
\hline Mila & 1.673 & 322.89 & 432.47 & 303.65 & 449.87 & 164.12 & 985 & 2.55 \\
\hline Padang Tiji & 7.022 & 1.355 .25 & 1.815 .19 & 1.274 .49 & 1.888 .22 & 688.86 & 4.134 & 10.69 \\
\hline Delima & 2.193 & 423.25 & 566.89 & 398.03 & 589.70 & 215.13 & 1.291 & 3.34 \\
\hline Grong grong & 1.104 & 213.07 & 285.38 & 200.38 & 296.87 & 108.30 & 650 & 1.68 \\
\hline Indra Jaya & 4.308 & 831.44 & 1.113 .62 & 781.90 & 1.158 .42 & 422.61 & 2.536 & 6.56 \\
\hline Peukan Baro & 4.086 & 788.60 & 1.056 .23 & 741.61 & 1.098 .73 & 400.84 & 2.406 & 6.22 \\
\hline Kembang Tanjung & 3.425 & 661.03 & 885.36 & 621.64 & 920.98 & 335.99 & 2.017 & 5.21 \\
\hline Simpang Tiga & 4.495 & 867.54 & 1.161 .96 & 815.84 & 1.208 .71 & 440.96 & 2.647 & 6.84 \\
\hline Kota Sigli & 117 & 22.58 & 30.24 & 21.24 & 31.46 & 11.48 & 69 & 0.18 \\
\hline Pidie & 5.016 & 968.09 & 1.296 .64 & 910.40 & 1.348 .80 & 492.07 & 2.953 & 7.63 \\
\hline
\end{tabular}




\begin{tabular}{lcccccccc}
\hline Batee & 3.906 & 753.86 & 1.009 .70 & 708.94 & 1.050 .32 & 383.18 & 2.300 & 5.94 \\
Muara Tiga & 4.878 & 941.45 & 1.260 .96 & 885.36 & 1.311 .69 & 478.53 & 2.872 & 7.42 \\
\hline Total & $\mathbf{6 5 . 7 1 5}$ & $\mathbf{1 2 . 6 8 3 . 0 0}$ & $\mathbf{1 6 . 9 8 7 . 3 3}$ & $\mathbf{1 1 . 9 2 7 . 2 7}$ & $\mathbf{1 7 . 6 7 0 . 7 6}$ & $\mathbf{6 . 4 4 6 . 6 4}$ & $\mathbf{3 8 . 6 9 1}$ & $\mathbf{1 0 0 . 0 0}$ \\
\hline
\end{tabular}

Remark: $\left.{ }^{1)}[7] ; 2\right)[8]$; 3) [9]

Table Attachment 3. The Buffalo population based on age and conversion to livestock units (ST) and percentage of ruminants

\begin{tabular}{|c|c|c|c|c|c|c|c|}
\hline Sub-District & $\begin{array}{l}\text { Buffalo } \\
\text { Population } \\
\text { (unit) }^{1}\end{array}$ & $\begin{array}{l}\text { Buffalo } \\
\text { Weaning } \\
\text { Population } \\
\text { (unit) }^{2}\end{array}$ & $\begin{array}{l}\text { Buffalo after } \\
\text { Weaning } \\
\text { Population } \\
\text { (unit) }^{2}\end{array}$ & $\begin{array}{l}\text { Young } \\
\text { Buffalo } \\
\text { Population } \\
\text { (unit) }\end{array}$ & $\begin{array}{l}\text { Adult Buffalo } \\
\text { Population } \\
\text { (unit) }^{2}\end{array}$ & $\begin{array}{l}\text { Buffalo } \\
\text { Population } \\
(\mathrm{ST})^{3}\end{array}$ & $\begin{array}{c}\text { Percentage } \\
(\%)\end{array}$ \\
\hline Geumpang & 1.121 & 216 & 290 & 203 & 301 & 550 & 10.16 \\
\hline Mane & 1.079 & 208 & 279 & 196 & 290 & 529 & 9.78 \\
\hline Glumpang Tiga & 120 & 23 & 31 & 22 & 32 & 59 & 1.09 \\
\hline Glumpang Baro & 24 & 5 & 6 & 4 & 6 & 12 & 0.22 \\
\hline Mutiara & 171 & 33 & 44 & 31 & 46 & 84 & 1.55 \\
\hline Mutiara Timur & 258 & 50 & 67 & 47 & 69 & 127 & 2.34 \\
\hline Tiro/Truseb & 457 & 88 & 118 & 83 & 123 & 224 & 4.14 \\
\hline Tangse & 2.747 & 530 & 710 & 499 & 739 & 1.348 & 24.90 \\
\hline Keumala & 442 & 85 & 114 & 80 & 119 & 217 & 4.01 \\
\hline Titeue & 199 & 38 & 51 & 36 & 54 & 98 & 1.80 \\
\hline Sakti & 359 & 69 & 93 & 65 & 97 & 176 & 3.25 \\
\hline Mila & 226 & 44 & 58 & 41 & 61 & 111 & 2.05 \\
\hline Padang Tiji & 1.381 & 267 & 357 & 251 & 371 & 678 & 12.52 \\
\hline Delima & 355 & 69 & 92 & 64 & 95 & 174 & 3.22 \\
\hline Grong grong & 60 & 12 & 16 & 11 & 16 & 29 & 0.54 \\
\hline Indra Jaya & 241 & 47 & 62 & 44 & 65 & 118 & 2.18 \\
\hline Peukan Baro & 249 & 48 & 64 & 45 & 67 & 122 & 2.26 \\
\hline Kembang Tanjung & 174 & 34 & 45 & 32 & 47 & 85 & 1.58 \\
\hline Simpang Tiga & 369 & 71 & 95 & 67 & 99 & 181 & 3.34 \\
\hline Kota Sigli & 14 & 3 & 4 & 3 & 4 & 7 & 0.13 \\
\hline Pidie & 51 & 10 & 13 & 9 & 14 & 25 & 0.46 \\
\hline
\end{tabular}




\begin{tabular}{lccccccc}
\hline Batee & 99 & 19 & 26 & 18 & 27 & 49 & 0.90 \\
Muara Tiga & 837 & 162 & 216 & 152 & 225 & 411 & 7.59 \\
\hline Total & $\mathbf{1 1 . 0 3 3}$ & $\mathbf{2 . 1 2 9 . 3 7}$ & $\mathbf{2 . 8 5 2 . 0 3}$ & $\mathbf{2 . 0 0 2 . 4 9}$ & $\mathbf{2 . 9 6 6 . 7 7}$ & $\mathbf{5 . 4 1 3 . 6 1}$ & $\mathbf{1 0 0 . 0 0}$ \\
\hline Remark: $:{ }^{1)}[7] ;{ }^{2)}[8] ;{ }^{3)}[10]$ & & & & & &
\end{tabular}

Table Attachment 4. The Potential for Feed and Total Production of Food Crop Waste (tonnes / year) in Pidie District, 2018

\begin{tabular}{lccccccc}
\hline \multicolumn{1}{c}{ Sub-District } & Rice & Corn & Soybean & Mung Bean & Peanut & Cassava & $\begin{array}{c}\text { Total Waste Production } \\
\text { (DDM ton /year) }\end{array}$ \\
\hline Geumpang & 926.21 & 0 & 4.62 & 1.096 & 11.508 & 12.15 & 955.58 \\
Mane & 1.207 .69 & 23.4 & 47.19 & 1.644 & 221.392 & 0 & 1.501 .32 \\
Glumpang Tiga & 2.020 .36 & 60 & 44.22 & 0 & 0.822 & 0 & 1.125 .40 \\
Glumpang Baro & 1.222 .20 & 0 & 0 & 0 & 0 & 0 & 1.499 .46 \\
Mutiara & 1.493 .39 & 0 & 0 & 0 & 0 & 6.075 & 3.132 .93 \\
Mutiara Timur & 3.081 .26 & 29.4 & 21.45 & 0 & 0.822 & 0 & 2.790 .10 \\
Tiro/Truseb & 2.759 .52 & 0 & 30.03 & 0 & 0.548 & 0 & 2.248 .59 \\
Tangse & $2,201.79$ & 46.8 & 0 & 0 & 0 & 0 & 1.204 .57 \\
Keumala & $2,199.29$ & 0 & 5.28 & 0 & 0 & 0 & 4.171 .22 \\
Titeue & 1.557 .12 & 0 & 11.88 & 0 & 0 & 18.23 & 2.387 .24 \\
Sakti & 4.089 .39 & 15 & 18.15 & 0 & 0 & 48.6 & 4.835 .39 \\
Mila & 2.378 .99 & 0 & 8.25 & 0 & 0 & 0 & 1.795 .79 \\
Padang Tiji & 4.734 .80 & 81.3 & 4.95 & 1.37 & 0.822 & 12.15 & 530.28 \\
Delima & 1.678 .52 & 0 & 14.52 & 95.9 & 6.85 & 0 & 2.002 .68 \\
Grong grong & 469.53 & 0 & 0 & 0 & 0 & 60.75 & 1.946 .88 \\
Indra Jaya & 1.906 .62 & 0 & 0 & 2.192 & 2.74 & 91.14 & 0 \\
Peukan Baro & 1.943 .31 & 0 & 0 & 0 & 3.562 & 0 & 973.33 \\
Kembang Tanjung & 1.776 .33 & 0 & 0 & 0 & 0 & 0 & 0 \\
Simpang Tiga & 973.08 & 0 & 0 & 0 & 0 & 0 & 1.295 .97 \\
Kota Sigli & 0 & 0 & 0 & 0 & 0 & 0 & 536.55 \\
Pidie & 950.97 & 0 & 0 & 55.896 & 106.86 & 182.25 & 1.591 .35 \\
Batee & 441.14 & 63 & 21.45 & 0 & 10.96 & 0 & $\mathbf{4 3 . 1 1 0 . 0 5}$ \\
Muara Tiga & 1.498 .22 & 6.9 & 17.49 & 14.796 & 23.564 & 30.375 & $\mathbf{4 6 1 . 7}$ \\
\hline Total & $\mathbf{4 1 . 5 0 9 . 7 3}$ & $\mathbf{3 2 5 . 8}$ & $\mathbf{2 4 9 . 4 8}$ & $\mathbf{1 7 2 . 8 9 4}$ & $\mathbf{3 9 0 . 4 5}$ & & \\
\hline
\end{tabular}

Remark: [7] and [11] 
Table Attachment 5. The Beef cattle and buffalo population based on livestock unit, feed requirement and holding capacity

\begin{tabular}{|c|c|c|c|c|c|c|c|c|}
\hline Sub-District & $\begin{array}{l}\text { Beef Cattle } \\
\text { population } \\
(\mathrm{ST})^{1)}\end{array}$ & $\begin{array}{l}\text { DMD } \\
\text { Requirement } \\
\text { of beef cattle } \\
\text { (ton/year) }^{2)}\end{array}$ & $\begin{array}{l}\text { Buffallo } \\
\text { Populatio } \\
\mathrm{n} \\
(\mathrm{ST})^{1)}\end{array}$ & $\begin{array}{l}\text { DMD } \\
\text { Requirement } \\
\text { of buffalo } \\
\text { (ton/year) }^{2)}\end{array}$ & $\begin{array}{l}\text { Total } \\
\text { requirement } \\
\text { of DMD } \\
\text { (ton/year) }^{2)}\end{array}$ & $\begin{array}{l}\text { DDM } \\
\text { production } \\
(\text { ton/year })^{2)}\end{array}$ & $\begin{array}{l}\text { The potential of } \\
\text { DDM has not } \\
\text { been utilized } \\
\text { (ton/year) }\end{array}$ & $\begin{array}{l}\text { The total of capacity } \\
\text { (ST/year) }\end{array}$ \\
\hline Mane & 42 & 48 & 529 & 604 & 651.89 & 1.501 .32 & 849.43 & 745.12 \\
\hline Glumpang Tiga & 1.977 & 2.253 & 59 & 67 & 2.320 .35 & 2.125 .40 & -194.95 & -171.01 \\
\hline Glumpang Baro & 2.305 & 2.628 & 12 & 13 & 2.641 .19 & 1.222 .20 & 1.072 .11 & 940.44 \\
\hline Mutiara Timur & 3.036 & 3.461 & 127 & 144 & 3.605 .04 & 3.132 .93 & 2.748 .18 & 2.410 .69 \\
\hline Tiro/Truseb & 878 & 1.001 & 224 & 256 & 1.256 .40 & 2.790 .10 & 2.447 .45 & 2.146 .89 \\
\hline Tangse & 697 & 794 & 1.348 & 1.537 & 2.330 .62 & 2.248 .59 & 1.972 .45 & 1.730 .22 \\
\hline Keumala & 673 & 767 & 217 & 247 & 1014.43 & 2.204 .57 & 1.933 .83 & 1.696 .34 \\
\hline Titeue & 422 & 481 & 98 & 111 & 591.90 & 1.587 .22 & 1.392 .30 & 1.221 .32 \\
\hline Grong grong & 650 & 741 & 29 & 34 & 774.57 & 530.28 & 465.15 & 408.03 \\
\hline Indra Jaya & 2.536 & 2892 & 118 & 135 & 3.026 .35 & 2.002 .68 & 1.756 .74 & 1.541 .00 \\
\hline Peukan Baro & 2.406 & 2.743 & 122 & 139 & 2.881 .82 & 1.946 .88 & 1.707 .79 & 1.498 .06 \\
\hline Kembang Tanjung & 2.017 & 2.299 & 85 & 97 & 2.396 .20 & 1.776 .33 & 1.558 .19 & 1.366 .83 \\
\hline Simpang Tiga & 2.647 & $3 . .017$ & 181 & 206 & 3.223 .47 & 973.08 & 853.58 & 748.76 \\
\hline Kota Sigli & 69 & 79 & 7 & 8 & 86.36 & 0 & 0.00 & 0.00 \\
\hline Pidie & 2.953 & 3.367 & 25 & 29 & 3.395 .28 & 1.295 .97 & 1.136 .82 & 997.21 \\
\hline
\end{tabular}




\begin{tabular}{lcccccccc}
\hline Batee & 2300 & 2.622 & 49 & 55 & 2.677 .10 & 536.55 & 470.66 & 412.86 \\
Muara Tiga & 2.872 & 3.274 & 411 & 468 & 3.742 .32 & 1.591 .35 & 1.395 .92 & 1.224 .49 \\
Total & $\mathbf{3 8 . 6 9 1}$ & $\mathbf{4 4 . 1 0 8 . 1 4}$ & $\mathbf{5 . 4 1 3 . 6 1}$ & $\mathbf{6 . 1 7 1 . 5 2}$ & $\mathbf{5 0 . 2 7 9 . 6 6}$ & $\mathbf{4 3 . 1 1 0 . 0 5}$ & $\mathbf{3 4 . 7 2 2 . 2 3}$ & $\mathbf{3 0 . 4 5 8 . 1 0}$ \\
\hline Remark: ${ }^{1)}[10] ;{ }^{2)}[11]$ & & & & & & &
\end{tabular}

